\title{
A Revolutionary Vision Reshaping History in Mahmoud Diyab's Gate to Conquest.
}

\author{
Amani Wagih ABD Al-HALIM \\ Cairo University
}

Since its early rise in Greece twenty-five centuries ago, theatre has been strongly associated with freedom and the democratic process. This has also been the case with Arabic theatre, as it calls for freedom of expression on the national and personal levels. Hence, the aim of this paper is to highlight the revolutionary vision adopted by the Egyptian dramatist Mahmoud Diyab in his play Gate to Conquest through the employment of different dramatic tools. Many studies have approached the Egyptian theatre from analytical or textual perspectives. However, I believe semiotics to be more fit as an approach that, to the best of my knowledge, was not utilized, in order to convey the political message of the Egyptian theatre in the 1960s and early 1970s. Martin Esslin explains the important role of dramatic signs in expressing various dimensions, and in turn conveying different meanings to the conscious spectators:

In a dramatic performance you are getting audio-visual images of that type at every second and in each second the image on the stage... contains an enormous amount of items, 'bits', of information. Thus we can say that drama, on the stage... communicates multidimensionally at any moment an almost inexhaustible amount of information and meaning. (37)

Therefore, this paper will adopt a semiotic approach pinpointing the dramatic elements used in the play namely, significance of names, and manipulation of time, space, light, character distances as well as segmentation of text. In other words, this approach will bring to light the dramatist's attempts to reshape history being the only way to achieve the lost democracy and human dignity in the Arab nation.

Classical Papers, vol. xi , 2012 


\section{A Revolutionary Vision Reshaping History in Mahmoud Diyab's Gate to Conquest.}

In the 1960s and early 1970s, most of the Arab nation was controlled by dictatorial regimes that relied on strict censorship to repress any opposition expressed in art. However, as critic Sabry Hafez believes "theatre plays the role of the popular parliament in which both writers and audience debate issues of great concern to them and their society" (10). Egyptian dramatists at that time held up the mirror to reflect the reality of the social and political conditions with the aim of raising or enhancing their audience's consciousness. Their plays highlighted the practices of corrupt oppressive regimes and called for democracy.

Saad Ardash describes Mahmoud Diyab as one of "the Liberated Dramatists who contributed in establishing a modern Egyptian theatre" (Ardash), along with Saad Al-Din Wahba, Yussif Idris, Aly Salem, Alfred Farag, Mikhail Roman, Numan Ashour and others. In most of his works, Diyab is overwhelmed with the concept of revolution and the Palestinian issue. He is compared to Shakespeare because throughout his plays, Diyab addresses human issues or humanity at large, not simply events that are soon forgotten: "Diyab's theatre resembles Shakespeare's in the sense that it is never considered outdated... because both of them dealt with humanity rather than mere events which soon become just memories of the past" (Abou Bakr 237). In his Gate to Conquest and other plays as Strangers do not Drink Coffee, Diyab discusses the Palestinian crisis considering it an embodiment of the Arab dilemma at large. Edward Said describes the reasons for the universality of Palestine denoting its cultural, religious and human aspects exemplified in its acceptance of the Other, despite its suffering from violation of human rights:

Palestine is perhaps of all places on earth the most densely saturated with cultural and religious significance, precisely that reality makes it an instance of universality thwarted and flouted. The universality of human co-existence, the human acceptance of the Other, and the human construction of a just and fair society for all- and certainly not only for some of its residents- are all relevant principles... Palestinians 


\section{Amani ABD Al-HALIM}

embody perhaps the most visible and certainly the most universal case of human rights abuses on earth today. (Said 17, 19)

According to Diyab the Arabs lost Palestine, the icon of their pride and power, when they were separated by being indulged in materialistic and personal benefits, and the only solution to restore their power is through reunion by changing themselves, in other words, revolutionizing against material gains or personal glory. This revolutionary vision against oppression, injustice and corruption is summarized by the words of the young protagonist, Usama, and his young supporters; they are conscious of the plights of their nation that necessitate a revolution:

Usama: The secret passages of intrigue and hangings, the devilish machinery of torture and horror, schemes of well distinguished concubines, verses of false flattering poets, books of ignorant scholars, the whips of money changers, traffickers in slaves, palms itching with bribery, pimps and robbers of public treasury... And from these ruins a new immaculate nation rises.

Group with Usama: A young nation capable of confronting the Franks and any nation yet unknown.

Our people remain the greatest in the history of Man. (49-50)

In Gate to Conquest, Diyab seems to be predicting the future, the Arab Spring Revolutions, as the makers of change are the Arab youth. Young men and women, revolting against oppression and calling for democracy and dignity in Tunis, Egypt, Libya, Yemen and Syria, are the same dramatic persona in Diyab's play. Their voices repeat the same slogans of the Arab Spring Revolutions: food for all, freedom for all and social justice for all.

If we liberate all people and give each one a little piece of land, and remove all causes of fear. We'd have a huge army of soldiers ready to die for what they possess, in the knowledge of what they have: freedom, an inch of land and the water of a spring, the ancestors' tomb, hope in the future and the mirth of a little girl playing in the shade of 


\section{A Revolutionary Vision Reshaping History in Mahmoud Diyab's Gate to Conquest.}

her home, memories of love...In the briefest of terms, the greatness of a nation. (150)

\section{Role of Names}

According to Marvin Carlson names provide a type of coding that the dramatist employs to direct his audience to a specific target through his work.

In the highly concentrated narrative world of the drama, the names given to characters potentially provide a powerful communicative device for the dramatist seeking to orient his audience as quickly as possible in his fictive world. (Carlson 27)

Diyab manipulates this dramatic device to juxtapose the pro-revolution figures and the anti-revolution ones. In this sense, the protagonist's name Usama is solidly attached in the minds of the audience to the conquests of the Islamic Empire. Usama is a purely Arabic name, given to a lion that is related to chivalry and courage; thus it fits the protagonist as he is a daring revolutionary figure carrying the torch of freedom and democracy throughout the play. His Arabic name mirrors his physical appearance and personal characteristics as the group of youth indicates:

GROUP [In a matter-of-fact tone]: The unknown revolutionary appears in Salah El-Din's age.

Y1: He's, necessarily, an Arab.

Y2: And of course, he's young.

Y3: And he must be a horseman, a knight.

Y4: He's master of the code of chivalry.

Y5: He's got courage, intelligence and virtue. (24)

Moreover, the use of Salah El-Din's name intensifies the sense of power, chivalry and hope for a better future. Salah El-Din is the eminent Arab leader who conquered the Crusades and restored Jerusalem to the Islamic Empire. As a historical figure he symbolizes the pride of the Islamic nation at large. In the context of the play, Salah El-Din is a renowned warrior but not a revolutionist. Therefore, the group of youth creates Usama to complete the concept of the revolution, the change to democracy that is to be achieved by thought not swords. Swords can create a military victory, 


\section{Amani ABD Al-HALIM}

but not a revolution aiming at social justice; Diyab "takes a contemporary view of Arab history where the significance of victory is incomplete without social justice" (Rubin 86).

Y4: Salah El-Din was a man of war, not of thought. Revolution and reform are born of thought. I'm not surprised his conquests died with his death. Some even petered out in his lifetime. If he had carried some thought or ideas alongside with his sword, we might've inherited his victories. (22)...

G2: Let's have him [Usama] appear in Salah El-Din's days. Let's have them meet. How fascinating! What do you think? The age that brought forth Salah El-Din, the warrior, could give birth to a revolutionary. (23)

Similarly, the scholar who believed in Usama's revolutionary vision and supported him is called Ziyad, which is also an Arabic name relevant to chivalrous attitudes as it connotes abundance and fertility. At the end of the play, he memorizes Usama's book and will transmit it everywhere, after all copies of the book are burnt and Usama's disciples are captured. Ziyad confirms to Usama that he will persist on revealing the truth to others who are still ignorant. In this sense, Ziyad intends to perform the street media that the young revolutionary figures in the Egyptian Revolution are undertaking to unveil reality.

There'll never be an end to your book. I'll take every opportunity to recite its words to the people whether they like it or not, in the market places, at the doors of mosques and churches, at road entries. I'll gather the youngsters and make them memorize the words. (145)

Abou Al-Fadl is the old man who protects Usama from the soldiers. He has witnessed the Crusader's occupation of Jerusalem in 1099 and is shocked to find out that two Jewish women, Sarah and Simone (typically Hebrew names), have usurped his house when he returns to Jerusalem to restore it. Ironically, Abu al-Fadl is also the name of an Arab village in the region of Al-Ramla in Palestine. The Zionists depopulated this village during the Arab-Israeli war after committing a massacre in February 1948. In other 


\section{A Revolutionary Vision Reshaping History in Mahmoud Diyab's Gate to Conquest.}

words, as the Jewish women occupied the Palestinian house in 1187, the Zionists repeated the same transgression in 1948. (Online digital library).

On the other hand, the anti-revolution figures are the tyrants who surround the ruler, in this case Sultan Salah Al-Din, with the aim of protecting their personal interests and hiding the truth from the ruler. A member of this group is the hypocrite historian, whose name and occupation are ironical. His name is Emad, which means in Arabic a person that one can depend on, and being a historian he should be a trustworthy person, but he delusively portrays the victories of Salah Al-Din and hypocritically praises him and his followers. Besides, being a poet he is supposed to be a man of intellect, but he refuses to argue with Usama when he finds himself getting convinced by the revolutionary vision of the young protagonist:"[Scared] No. I won't! I could dispute and argue with a Crusader, but I'll never argue with a Muslim who's turned infidel!" (52). Another member of the same group is Seif El-Din, or the swordsman as his name indicates. He is the Sultan's greatest General and is equally afraid of Usama's thoughts; therefore he wants to get rid of him to protect his worldly gains:

[Turning the sword in his hand, resuming his thoughts] He's [Usama] got such venomous thoughts. If the mob listens to him, it'd grow dangerous... His words may appeal to the Sultan. Turning them into a code of government, he'll deprive me of my slave-girl, a most enchanting woman and ruin my prospects of getting an estate in Jerusalem. Shall I kill this lunatic from Andalus? (56-7)

The other tyrants of this group are types such as the Slave Merchant, the Seed Merchant and the Treasure Merchant. Their nameless designation indicates their role in the society standing for their counterparts as people seeking self-interest. Ken Whittingham in his article "Egyptian Drama" comments on the juxtaposed groups in the play pinpointing the aim of antirevolutionists:

In The Book of Conquests Osama, a revolutionary armed not with a sword but a book of knowledge, is trying to reach Sallah ad Din so that he may learn from the book 


\section{Amani ABD Al-HALIM}

and rule wisely. A circle of tyrants surrounds the ruler, desperate to destroy the threat of knowledge. (18)

Whittingham relates this juxtaposition to the political and social situations in Egypt in the Sixties, where Abdul Nasser was considered the good Sultan surrounded by corrupt ministers who sought their personal interest.

For the most part plays dealt with themes of immediate social relevance, from national liberation (Palestine and the war with Israel) through internal class struggle, to methods of government (typically represented as a good Sultan, i.e., Abdul Nasser, surrounded by bad ministers, i.e., the security services, corrupt ministers, etc.). (16)

Therefore, this play was banned in Egypt, although it was performed in Baghdad, Damascus and Algiers, in similar manner as Usama was prevented from meeting Salah Al-Din. At the end a circle of the tyrants surrounds Usama and he screams concluding with the only solution for the progress of the nation which is the elimination of corruption; a target that can be achieved through a revolution:

I know who you are! I know you all because I've often seen your faces in Andalus, Morocco, Egypt and the Levant, in all countries I've been to. I wish my comrades would come now to see your unholy gathering and discover the truth in your eyes: we are right. Conquests for this nation will never come true unless they march over all your bodies without mercy. (148)

\section{The Question of Time}

Diyab employs a dual time structure in the play by describing past events and discussing them in the present, portraying both on stage at the same time. The past presents the events of medieval time describing Salah AlDin's victory over the Crusades and the restoration of Jerusalem in 1187. At the same time, the present portrays the group of revolutionary youth who decide to relive the past to regain power with the aim of recreating history: "Let's take up history as a pastime to break the silence and preserve our portion of self-confidence. We're the descendants of a glorious nation 


\section{A Revolutionary Vision Reshaping History in Mahmoud Diyab's Gate to Conquest.}

whose deeds are preserved in thousands of volumes... We won't read history as it was recorded. We'll remake it" $(16,17)$. Then with the appearance of Usama, whom the group created, the past and the present are intermingled as both the group (representing the present) and the protagonist (representing the past) become one. The role of the youth group changes from commenting and narrating to participating in the course of the play. They start to repeat the slogans that Usama has written in his book which recall to mind the reasons for the Arab Spring Revolutions: food, freedom and dignity.

Y4: How can I be free when I'm hungry?

Y3: Despised like a stray dog.

Y4: Trodden.

Y1: Scared.

Y2: Eaten by the feeling that I'm chased and hounded, even in my dreams...

Y3: I push my head in the garbage bins looking for my lost pride...

Group: Set the slaves of this nation free. There is no freedom for the land without a free people. $(44,45)$

In other words, the group of idealistic youth living in the present are recalling the past to create a different future; their simple dreams are freedom and justice. Roman Jakobson coins the relation between the past, present and future as "we cannot imagine the present without the past, nor the future without the present" (14). However, in the play, the fusion of both present and past distorts the future, as the glorious past aspired to be recreated turns into a nightmare, when the modern young group find out that the past equally suffers from the tyranny of the ruling regime and oppression of self-will; a situation that Sabry Hafez describes as a "bitter irony".

The quest of the young group of men and women is relatively simple: freedom and social justice, but the response it produces through-out Arab history is depressing and even gruesome. The bitter irony of the play is that the young group of idealistic dreamers invoke 


\section{Amani ABD Al-HALIM}

a glorious period of Arab history to console themselves and derive from it positive inspiration. But this very glorious period turns into a nightmarish one in which people of their ilk are deprived not only of the freedom of speech, but also of thought, will and action. (23)

\section{Functions of Dramatic Space}

According to Michael Issacharoff in his article entitled "Space and reference in drama," dramatic space is divided into two main types: mimetic and diegetic. Mimetic space is the one set on stage and is visible to the audience; in other words, it is visualized. On the other hand, diegetic space is the one that the characters give an account of or refer to; therefore, it depends on verbal rather than visual communication.

There are two major forms of dramatic space: mimetic and diegetic. This distinction parallels what narratologists have been inclined to call showing and telling. In the theatre, mimetic space is that which is made visible to an audience and represented on stage. Diegetic space, on the other hand, is described, that is, referred to by the characters. In other words, mimetic space is transmitted directly, while diegetic space is mediated through the discourse of the characters, and thus communicated verbally and not visually. (215)

In his Gate to Conquest, Diyab manipulates both forms to convey his perspective. The interplay between mimetic and diegetic spaces enriches the context of the play and highlights its political message. Since the onset of the play, mimetic space describes scenes of either oppression or depression. One of these scenes portrays the continuous victories of Salah Al-Din and the seizing of Acre. Inhabitants of the city, who were expelled by the Franks, are returning to their homes; however, ironically this scene of supposed joy and celebrations turns to a scene of depressed citizens because the soldiers of oppressive commanders (as Seif El-Din) prevent them from entering their city: ".. a crowd of Arab citizens are gathered in front of it trying to enter. They make a loud noise. Angry faces of Arab soldiers look out of a big window at the top of the gate" (63). Corrupt 


\section{A Revolutionary Vision Reshaping History in Mahmoud Diyab's Gate to Conquest.}

figures as the hypocrite historian and the tyrannical commander are the ones admitted to enter the recently liberated city: "A small gate at the foot of the gate opens. Emad enter[s] quickly before it closes... Seif El-Din appears at the peephole in the gate" $(64,65)$.

However, the scenes of disappointment shift to an aura of hope for a better future upon the appearance of the revolutionary protagonist, who fearlessly unveils the mask of corruption, after the crowds choose him to be their spokesman. Usama, supported by the common people, confronts the oppressive tyrants:

Slight din among the citizens. They look around at each other, then they settle on Usama. Silence. They split in two wings and Usama is left alone in the middle.

Emad and Seif [Crying out]: You?!

Citizens: This youth speaks for us...

Usama [To Seif and Emad]: Why should you lock the doors against the city owners?... You need respite to establish order in the city before the people enter and spoil your regime. Order is those lists, the same old lists brought back to life. People die, faces change, but the lists stay... All these people, the poor in all ages are grouped in one square at the tail end of the list... in their place, the city's junkyards, your animals' stalls, the roofless dwellings of your fields and pastures, the beggars' stations at your doorsteps and front of mosques... (67-68).

This change in mimetic space paves the way to the diegetic space where the dreams turn to be nightmares. Diyab employs diegetic space to reveal another kind of oppression, that of occupation. The scenes narrated by Abou Al-Fadl about the massacres of the Franks when he was a little child, remind the audience of mass extermination of Palestinians in the occupied territories:

The gate of the Aqsa mosque there, behind me. I walk in a straight line. I cross the square. These are the same stairs. I used to rush out of our home jumping the steps, then there was the crowded market. There used to be a market place in the square. There was a sweet shop beside the stairs. The 


\section{Amani ABD Al-HALIM}

man used to give me so many sweets. I don't remember his name now, but I do remember that he was slaughtered in the square. I stuck to the door of our house watching the massacre, the flames of fire breaking out in the mosque over there. I was shaking, I heard the city shrieking ... My mother ran after me to get hold of me. I saw a devil on a black horse rushing at my mother with his drawn sword. She screamed, run, fly, and she was stabbed in the chest. She fell down on these stones. (113-14)

However, when Abou Al-Fadl returns to his city aspiring for reliving in his home, he discovers that the Jewish women have occupied his place. No one supported his right to regain his house except the revolutionary group and Usama, whereas others namely the corrupt circle of tyrants advocate the Jewish women's usurpation of the house against the old man. Sarah and her daughter Simone have lured the corrupt characters who are always ready for worldly pleasures and temptations. All dreams change into nightmares, a case that leads Usama to admit bitterly to himself that reality is "much more complex than I have ever imagined in my dreams, over there on the green hill" (119). At the end of the play both mimetic and diegetic forms blend together so that space disappears due to the continuous series of corruption and oppression, but the revolutionary vision will never fade. In the final encounter between Usama and Ziyad the violation of space is evident, as Usama is scrambling everywhere trying to convey his message; however, the revolution exemplified by his book will survive:

Ziyad: ... Where do you live now, Usama?

Usama: Nowhere. [He laughs briefly and sadly] I'm moving between places. I don't settle anywhere ... [He extends his hand to take the book] Is this a new copy? (144)

Portrayal of space in the play does not depend on detailed description of the setting; hence Diyab favors the theatrical trend that aims at conveying the dramatic message without excessive details. Absence of detailed setting in modern theatre is a trend that reveals the new tendency which appeared at the beginning of the $20^{\text {th }}$ century and the belief that such displays distract 


\section{A Revolutionary Vision Reshaping History in Mahmoud Diyab's Gate to Conquest.}

the audience from evaluating the dramatic work: "detailed illusionistic settings...have rarely been seen in the modern theatre, partly in reaction to the turn- of- the -century excesses in such productions, and partly due to a feeling that such displays distracted from other and more important values of the dramatic work" (Carlson 79).

\section{The Dramatic Function of Light}

At the beginning of the play, light is relevant to the revolutionary vision. The first appearance of the revolutionary protagonist is indicated by a spotlight denoting hope for a better future, added to that is his body posture assuming pride and self confidence as seen "standing straight"(24). Then soon afterwards, he is presented once more in a spotlight, but this time he is sitting on "top" of a hill holding a "big book" (26), thus conveying his deep thoughts. The audience is prepared to meet a young man who is proud of his identity and is preoccupied with the troubles of his nation. The account given by the modern young group before Usama's first words asserts the notion of revolution: "Because he called for change, his ideas disturbed the authorities, made them anxious, kindled their wrath and Usama was often chased by the police" (26). Another instance of light identifies the group of idealistic youth "in deep contemplation" reaching the conclusion that knowledge is power "I suggest to add to Gate to Conquest a paragraph that who masters science dominates the world" (60).

However, the function of light changes as it starts to indicate the bitter irony of the dramatic situation when dreams turn into nightmares, and the past lacks the inspiring power for a better future. Jerusalem that is supposed to be the place of security, justice and pride of the Arab nation appears to be a place surrounded by soldiers collecting fines from Franks leaving the city, as the spotlight reveals. According to Ahmed Sakhsokh, Diyab chooses the city of Jerusalem because it represents a complicated issue

[that] is closely related to the conflict in the Arab world and at the same time should pave the way to achieve peace in the region. Because it measures general public opinion in the Arab region, it can never be separated 


\section{Amani ABD Al-HALIM}

from the intellectuals. Consequently, theatre which portrays human conscience can not be isolated from one of the most important issues in the region.

Salah Al-Din conquered the Crusaders in Hittin and recaptured Jerusalem on October 2, 1187: "In 1187 Saladin wiped out the army of the crusaders in the famous battle of Hittin, and in consequence of that great victory, he was able to take possession of almost all of Palestine and most of Syria" (Ehrenkreutz 110). Despite the almost achieved aspirations of a better future, nightmares smudged the scene. Upon the threats of Jerusalem's Frank ruler to kill Muslim hostages and to destroy the Dome of the Rock and Al-Aqsa Mosque, Salah Al-Din unwillingly spared the lives of the Franks, ransoms were accepted and he permitted the Jews to resettle in the city.

Now the spotlight, in the play, shows characters suffering from injustice and humiliation: Abou Al-Fadl lies on the ground in front of his usurped house after failing to achieve his life-dream of returning to his home, and the young group of Usama's supporters are imprisoned after failing to meet Salah Al-Din to deliver his book that comprises his revolutionary vision.

\section{Character Distances}

In theatrical performance, distances are divided into four categories termed as interstitial distances: intimate (touching, or near touching), personal (two-person conversation), social (small group conversation) and finally public (large group meetings); as Keir Elam explains: "intimacy, personality, sociality and publicness are ...the four major cultural units assigned to segments of the spatial continuum" (65). Diyab employs these four types to clarify his political message where his protagonist is involved. Intimate distances are rarely utilized since they indicate warm feelings that the oppressed Arab citizens are deprived of. Therefore, they are used to foreshadow the friendship relation to be between Usama and Ziyad as one of his supporters. When Ziyad knows that Usama is an Andalusian who arrives to polish off the victories of Salah Al-Din by his revolutionary mission, he shakes hands with him, and always stands close by him. His 


\section{A Revolutionary Vision Reshaping History in Mahmoud Diyab's Gate to Conquest.}

other group of young supporters also has intimate distances with him and with each other. "Standing on his side... [and sitting] very close" to each other (112) signifies their union and support of the idea of revolution for the sake of a better future. Personal distances equally convey the same message, and all of them take place between Usama and Ziyad. These instances are presented immediately after the intimate ones to confirm Ziyad's complete belief in Usama's ideas and predict his role in helping Usama at the end of the play. Their dialogue therefore changes from questions (Ziyad) and answers (Usama) to an interchange of ideas that complete each others:

Usama: Our nation is afflicted with senility, obesity and endemic cancers...And the Franks are sharp. They know all that. They'll push on to destroy us completely, unless something happens.

Ziyad: A divine miracle?

Group with Usama: A miracle of our making.

Ziyad: We? Us! (49)

On the other hand, the social and public distances are employed to demonstrate the scenes of oppression and corruption. Arguments, not discussions, are therefore used throughout these scenes. One of the social distances occurs when Emad, the corrupt historian, is arguing with Usama and his young supporters in their revolutionary ideas. Ironically, Emad who is supposed to be a man of intellect and culture is a hypocrite. He praises Salah Al-Din's victory refusing to understand the youth's words, and even making fun of their ideas.

Emad: He's [Usama] using the language of prophets!

Group: I speak in the name of all the enslaved..

Emad: All weaklings!

Group: Your slaves are of two types..

Emad: I only know one, unless he's given the females a class of their own!

Group: One is bought and sold on the market. The other is made slaves of fear and need.

Y1: This is the normal in our nation, except for the masters and their hirelings... 


\section{Amani ABD Al-HALIM}

Emad: This young man envies the masters!

Group: No, no, he's in sympathy with the slaves.

A significant scene of public distance takes place at the end of the play, when the tyrant commander, Seif El-Din, is infuriated and appalled upon finding out the increasing number of Usama's young supporters everywhere trying to transmit his message. The tone dictated by the stage directions reveals the threatening fury and rage of Seif El-Din as opposed to the selfconfidence, stability and persistence of the young revolutionaries. The intensified disturbance of the commander is a direct outcome of his tyranny and corruption, in this scene Diyab seems to be describing the practices of the unjust power against its people that caused the eruption of the Arab Spring Revolutions.

Soldiers: He's got nothing, only this book.

Seif: Where do you come from?

Y4: Damascus...

Seif: ... What's your name?

Y4 [Calmly]: Usama BnYa'cub.

Seif [Excited]: That's a lie! ... (127)

Seif [Closes the book nervously, then shouts]: What's your name, you scoundrel?...

Y5: Usama Bn Ya'cub...

Soldiers: Where do you come from?

Y5: From Cairo...

Seif: ... Where's your boss? [Pause] How many are you? [Pause] Is the Andalusi in Jerusalem? [His questions follow one another] How has this book circulated among you? Where do you live? How did you meet here? [Silence] You don't answer, but we've got ways of torture that'll make you speak.

Y5: Your torture isn't worse than what life offers us on this earth. (136)

\section{Segmentation of Dramatic Text:}

Though the play is written in three acts, it is internally divided into three major situations that highlight the political message of the play presented 


\section{A Revolutionary Vision Reshaping History in Mahmoud Diyab's Gate to Conquest.}

by the protagonist. The importance of this is clarified by the remark that each of these scenes offers "a self-contained unit and... a link in the structural chain," of the play (Aston \& Savona 17). The revolutionary protagonist, Usama, is the common dominator of the three scenes as he meets three different categories of people, to whom he tries to express and explain his message. In Act One, the first type is the most prestigious and influential characters such as the supposedly cultured historian and the great commander. Ironically, these characters who are supposed to comprehend Usama, as they are defending the prosperity of the nation, completely ignore him. They even refuse to listen to his words and try all ways to prevent him from meeting Salah Al-Din. As this kind of people believes in materialistic gains and personal glory, they never understand Usama or believe that he does not aspire for money or position; they attack him wildly defending their acquired positions and interests.

Emad: ... And...and...I don't think, Seif El-Din, you need to know anymore. It only remains for him [Usama] to deprive us of food and drink.

Seif [Depressed]: Oh, are all these things in the book?

Emad: Yes.

Usama: But that isn't all! It's only a little part of the book.

The sheikh [Emad] hasn't read the book. He only browsed in it ...

Seif [To Usama]: And you expect the Sultan to give you a handsome reward!

Emad: He may even aspire to become the wise spokesman of the Sultan and his favorite scribe!

Seif: He may even crave to become a minister! ...

Usama [Shouting]: Will you please stop. [Pause] I can discuss with you what I've written if you wish. (55-6)

The second scene takes place in Act Two when Usama meets the common people. These simple poor citizens, who are deprived of the basic human needs even secure homes, are the ones who understand Usama and nominate him as their spokesman. They are turned down by Seif El-Din and Emad when they resort to them asking for justice: the former threatens and the latter prepares himself to deliver a long nonsense speech. 


\section{Amani ABD Al-HALIM}

Seif: Listen to me! Silence! [Riots continue] If you don't listen to me, I'll have you shot with burning catapults! ... I'm good at fighting but no good at talking. This sheikh will speak to you ... Come on Emad El-Din! ...

Citizens: Speak to the Sultan for us, Sheikh.

Woman: Tell him to look on us.

[Emad taking a pious posture, clears his throat and makes ready to deliver a long speech]

On the contrary, Usama is the one who understands these poor people and appreciates their sufferings; therefore, he advocates their cause and they support him. Unlike the tyrants representing the first category, Usama estimates the value of blood and respects it.

Usama: These people over there are the citizens of Acre.

Citizens: True!

Usama: Their sons and daughters fought alongside with you [soldiers].

Citizens: Also true!

Usama: they fought to restore the city to these citizens.

Citizens: Yes, to us!

Usama: Their fathers lived in all their lives but were driven out by force. Every one of them left traces of his blood in its soil. There's a tie of blood between them and the city.

Citizens: Its wells are full of our blood...Its soil is made of our grandfathers' slaughtered corpses. (65)

In Act Three, the third scene occurs between Usama and the group of youth, who support his revolutionary vision. They even decide to spread his ideas among their people, who are blinded to the truth: "Each one is going home with a copy of Gate to Conquest. All my countrymen love life, ... they're satisfied with the meager portion of it, because they don't know any better. Thick walls were erected all round them, keeping them in ignorance" (111). These idealistic dreamers never lose hope and persist on delivering their revolutionary mission. Therefore, at the end of the play when Seif ElDin wanders about their number, the wise old man Abou Al-Fadl answers: "Thousands, thousands, fighting and carrying books" (136). 


\section{A Revolutionary Vision Reshaping History in Mahmoud Diyab's Gate to Conquest.}

These three scenes recall to mind the revolutionary situations during the Arab Spring Revolutions. The enemies of these revolutions are always those of power, who hold posts and are never ready to sacrifice their positions or interests for the welfare of their countries. Dictatorial regimes succeeded in creating a corrupt web of interests comprising officials, employers and employees in all fields that benefit from the overdominating oppressive authority. In fact, they are not defending the dictatorial regime as much as they are protecting their own interests. On the other hand, the supporters of the revolutions are the common people, who have endured lots of sufferings and the persistent idealistic youth, who will never give up hope for a better future, a tomorrow that bears dignity to all citizens equally:

The term dignity (al-karama) has been resonating throughout the region as the underlying pillar of popular protests. This has to do with the fact that decades of dictatorship, economic failures, crony capitalism, corruption and cultural decline have stripped the average citizen of their political, social and economic rights as dignified human beings. As a result, the region was in a political and social deadlock for decades. (Hassan)

In fact, history repeats itself; absence of democracy, oppression, poverty, corruption and social injustice are the same plights that caused the decline of the Islamic Empire and the glorious history of the Arab nation. Tyrants' voracious desires to worldly gains and pleasures resulted in economic inequality, political and cultural suppression practiced against their nations. Therefore, an urgent solution is fervently sought, a call for democracy, as depicted in the play, where the young generation embody the unceasing determination to "set things right" (Mazhar 7). Through the employment of dramatic elements, Diyab highlighted the political message concerning the Arab's lost dream and the endeavors of Arab youth to retrieve the nation's lost glory. His revolutionary vision against oppression can be achieved by reshaping history, a history that expresses the dreams and aspirations of the whole Arab nation, a new history based upon freedom, equality and justice through which the nation can regain its lost glory. 


\section{Amani ABD Al-HALIM}

\section{Notes}

Translation of Arabic sources is done by the present writer, except for the play.

\section{Works Cited}

Aston, Elaine \& Theatre as Sign-System. London \& New York: George Savona. Routledge.

1991.

Carlson, Marvin. Theatre Semiotics: Signs of Life. Bloomington \& 1990. Indianapolis: Indiana University Press.

Ehrenkreutz, A.S. "The Place of Saladin in the Naval History of the 1955.

Mediterranean Sea in the Middle Ages"

Journal of the American Oriental Society, Vol. 75, No. 2: $100-116$.

Elam, Keir. 1980. The Semiotics of Theatre and Drama. New York: Methuen.

Esslin, Martin. The Field of Drama. London \& New York: Methuen. 1987.

Hafez, Sabry. $\quad$ "The Quest for Freedom in Arabic Theatre"

1995. Journal of Arabic Literature, Vol. 26, No. 1/2: 10-36.

Hassan, Kawa. $\quad$ "Making Sense of the Arab Spring: Listening to the

2012

Voices of Middle-Eastern Activists"

http://www.palgravejournals.com

(accessed 1/3/2012)

Issacharoff, "Space and Reference in Drama"

Michael. 1981. Poetics Today, Vol. 2, No. 3: 211-224.

Jackobson, Verbal Art, Verbal Sign, Verbal Time. Minneapolis: Roman. 1985. University of Minnesota Press.

Moussa, Fatma \& Bab Al-Futuh (Gate to Conquest). Cairo: Foreign Mazhar, Amal Cultural Information Department.

(Trans.) 1999.

Rubin, Don. (Ed.) The Arab World Encyclopedia of Contemporary 1999.

Theatre. Vol. 4. London \& New York: Routledge.

Said, Edward. "Memory, Inequality and Power: Palestine and the 2004. Universality of Human Rights" Alif: Journal of 


\section{A Revolutionary Vision Reshaping History in Mahmoud Diyab's Gate to Conquest.}

Comparative Poetics, No. 24: 15- 33.

Wittingham, Ken. "Egyptian Drama" MERIP (Middle East Research and 1976. Information Project) Reports, No. 52:13- 19.

Online source: http://digital.library.wisc.edu. (accessed 11/2/2012)

$$
\begin{aligned}
& \text { المراجع العربية } \\
& \text { أبو بكر ، مدحت.V . . . T المسرح المصرى قضايا وعروض.القاهرة: المجلس } \\
& \text { الأعلى للثقافة. } \\
& \text { أردش، سعد.V. . . T لا سكة السلامة ولا سكة الندامة" حوار ماهر حسن } \\
& \text { مع سعد أردش. جريدة العربى لهاه } \\
& \text { سخسوخ، أحمد.9 . . " المسرح والمقاومة .. فلسطين نموذجاً في نصوص/ } \\
& \text { عروض المسرح المصري" ، مهرجان الكويت المسرحي } \\
& \text { الحادي عشر (العدد الثامن) }
\end{aligned}
$$

